\title{
Gender studies in the gender-blind post-socialist geographies of East-Central Europe
}

Les études de genre dans les géographies post-socialistes insensibles aux genres, le cas de la Hongrie

\section{Judit Timár}

\section{(2) OpenEdition}

\section{Journals}

Electronic version

URL: http://journals.openedition.org/belgeo/11217

DOI: 10.4000/belgeo. 11217

ISSN: 2294-9135

Publisher:

National Committee of Geography of Belgium, Société Royale Belge de Géographie

Printed version

Date of publication: 30 September 2007

Number of pages: $349-370$

ISSN: $1377-2368$

\section{Electronic reference}

Judit Timár, "Gender studies in the gender-blind post-socialist geographies of East-Central Europe », Belgeo [Online], 3 | 2007, Online since 11 December 2013, connection on 22 May 2020. URL : http:// journals.openedition.org/belgeo/11217 ; DOI : https://doi.org/10.4000/belgeo.11217

This text was automatically generated on 22 May 2020 .

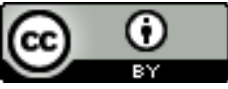

Belgeo est mis à disposition selon les termes de la licence Creative Commons Attribution 4.0 International. 


\section{Gender studies in the gender-blind post-socialist geographies of East- Central Europe}

Les études de genre dans les géographies post-socialistes insensibles aux genres, le cas de la Hongrie

Judit Timár

1 In the spring of 1993, MONA (Foundation for the Women of Hungary), then a recent organisation established in the midst of prevailing political party strife, held the first National Women's Roundtable in a Hungary that - having left the era when there was only one single "official" female organisation - was just learning the rules of the democracy game. Over 150 representatives from 25 existing female organisations ${ }^{1}$ including the female factions of the individual political parties, the Gypsy Mothers' Association and the Feminist Network, conducted good-humoured discussions which proved a great success. True, there were no public reverberations, as none of the invited journalists attended the event. Attendees concluded on a somewhat bitter note that there was no way that the male leaders of the individual masculinist political parties would have had a similar roundtable. Or if they had, it would have made frontpage news in all the dailies ${ }^{2}$ !

2 Speaking of publicity, will mainstream geographers pay attention to our thoughts about Anglo-American hegemony in the discipline and the possibilities of its contestation? Will feminist geographers from very different parts of the world, including the USA and the UK, be able to agree on the very essence of such hegemony and on the reasons why it deserves criticism ; to identify the necessary changes and the means to bring about such changes? In order for them to be able to do so, we should, in addition to identifying the characteristics of the production of knowledge in the field of gender and geography - which vary from one geographical place to the next - clarify our diverse experiences in and attitudes towards this hegemony as well as our interest 
in changing it. From an East Central European perspective, I find that two aspects are of key importance :

- The hegemony of Anglo-American work in geography has become obvious recently and has been the target of sharp criticism by critical geographers. This hegemony itself takes many forms. It manifests itself in geopolitical relations that vary in space and time. In an East Central European political and economic context, both mainstream and fledgling feminist geography struggle with the disadvantages arising from the inequalities between the "East" and the "West". This in turn reminds us of the fact that it is not just Anglo-American geography that encroaches on feminist geography in other countries, since the latter are also likely to be full of inequalities. If apparent conflicts of interest are to be resolved and tolerance and solidarity to be fostered, attention needs to be paid to learning about the rather intricate "power geometry". There is a need to raise awareness that belonging to a specific geographical place does not necessarily entail an entrenched position between the beneficiaries of power and those at the receiving end.

- In contrast, although in a different social, cultural, economic and institutional context and to varying degrees, the geographical knowledge which we feminist geographers produce (within a rather masculinst discipline) plays a marginal role the world over. Fighting for a radical change in this status quo is undoubtedly of mutual interest to us. Thus while we may wish to contest hegemonies within feminist geography, we also need to identify ways to work together.

3 In this paper, with this mutual interest borne, in all cases, in mind, I will outline a few characteristics as well as the local and international position of feminist geography in East Central Europe, while focusing on differences and inequalities. In the context of knowledge production by feminist geographers, difference can mean, for instance, the spatial diversity of the social, cultural, political and institutional circumstances that either encourage or restrict feminist geography and of the history and the relevant topics, concepts and theories of the discipline. There are, however, undisputed inequalities, created by capitalism, in access to funds for research and to publishing and publications, inequalities in the dissemination and dominance of theories and control over "international" journals and organisations, etc. The theme of this journal issue provides justification for placing an emphasis on the issue of "difference", since "Geography and Gender Worldwide" by itself suggests the acceptance of diversity. Yet if a goal is to challenge Anglo-American hegemony in order to give voice to those geographies that are marginalised, then, I think, we have not only to discover the differences but also confront the issues of inequalities among us.

In the first section of the paper I will take up the complex questions of the nature of hegemonies and the ways in which they reflect "inequalities", while also citing examples that demonstrates that there are differences, at an international level, in the manifestations of hegemony as well. I focus on the ways in which Western scholars took up new interest in post-socialist countries, bringing with them their own scholarly traditions and concerns and their dominant position in East-West joint projects and publications. Post-socialist transition gave rise to a unique debate on the differences and inequalities of Eastern and Western feminisms. This debate also touched on the issue of whether it is structural power and economic imbalances or power imbalances at the level of discourse that are to be blamed for the hegemony of a Western feminist discourse. Finally, I propose that post-socialist experience is likely to have an impact on 
"feminist geographic thinking" concerning hegemony and social and, hence, gender differences and inequalities in a broader sense.

5 The second major section - focusing on the issue of differences - traces the characteristics of geographic work on gender in East Central Europe highlighting first the symptoms and social and institutional causes of marginalisation and then topical and geographical foci of the research. These characteristics are interpreted against Western (or Anglo-American) feminist geography. These sections are followed by some concluding remarks on "which differences matter" when we seek to resolve hegemony and on the inequalities that the tools at the disposal inside academic world may help to reduce.

\section{Anglo-American and western hegemonies : different forms of unequal relations}

The recent international debate on the hegemonic nature of geographical knowledge production has resulted in the dominance of Anglo-American hegemony having become a widely held tenet. In 1998, Berg, for instance, labelled, from the perspective of the "South" and other "peripheries", the US and Europe as centres of academic production (Berg in Katz, 1998 ; Berg and Kearns, 1998). From an East Central or Eastern European perspective, i.e., for those outside the power centre of Europe, "AngloAmerican" is a more accurate approximation of the status quo than the term "EuroAmerican", which he used, although "Western hegemony" would probably be a more apt term. This was particularly true in the first few years after the political changes in 1989 and 1990 ; that is, it is the set of "East-West" economic and geopolitical differences/ inequalities that seems to best characterise the bipolarity of the power relations of academic life. Economic backwardness in the Eastern part of Europe translates into material differences in GDP. The after-effects of a world order based on the antagonism between capitalism and state socialism are still reflected in the EastWest dichotomy of politics and culture, albeit in a much more intricate global geographic setting.

7 When we turn to the geography of gender, we cannot really speak of hegemony in relation to the East Central Europe of the pre-1989 and 1990 political changes. The field simply did not exist under socialism. As for mainstream geography and, within this, Hungarian practices, with which I am mostly familiar, in the socialist era the issue of the hegemonic nature of geographical knowledge production never cropped up in public debates. The obvious reason for this was that hegemony was less based on, for example, publication power than on the Marxist ideology of the Soviet regime, a tenet that could not be challenged under authoritarian conditions. This practice was the subject of criticism with the enthusiastic worship of the West after the political changes. The experience that we have gathered over the past one and a half decades, however, has dispelled a good number of the illusions that we used to entertain about academic public life in the West. Western hegemony has presented itself in at least three different ways in geography (and in several other social sciences), although in a manner that varied in time and from one place to the next : (i) an invasion of the East by "EU experts" exploiting cheap labour in the early 1990s ; (ii) the "expropriation" of East Central Europe as a field of research; and (iii) inequalities in East-West joint projects (Timár, 2004a). Of them, (ii) and (iii) made themselves felt, albeit indirectly, in 
the field of gender and geography through the disadvantages that mainstream geography and gender studies in other disciplines of social sciences suffered from. What follows illustrates such disadvantages.

\section{The differing impacts of Westerners taking a sudden interest in the East}

8 A sudden upsurge in interest in East Central Europe benefited us researchers in the region quite significantly, as it offered us a gateway to the West, opening up opportunities (such as scholarships, visiting fellowships and projects) never before experienced. The use of the first person plural is inappropriate, however, as former Soviet bloc countries were far from being on an equal footing with each other. In the 1990s, for instance, geographers from Moldova or Bulgaria, unlike a rapidly increasing number of their counterparts in other countries in the region (who had been able to rely on scholarships to universities in Western Europe for their education), did not submit any applications under the Research Support Scheme of the Soros Foundation which funded research in social sciences in the post-socialist region. They may not even have been aware of the possibility. Applicants from the successor states of the former Soviet Union often spent the bulk of the money they obtained on reference books published in the West, as this was the only way they could have access to such books.

9 Naturally, it is hard to assess which "party" has benefited more from the demolition of the Iron Curtain between the East and the West. One thing is sure, however, namely that technical literature on the post-socialist region published, hopefully for the greater good, in the past one and a half decades could easily fill up an "entire library". A closer look at this literature reveals the dominance of the West and, in particular, Anglo-American dominance. Of the 14 books on gender issues in East Central Europe that I found in Hungarian libraries and that were written in English, only one was published in the region (Feischmidt et al., 1997). Of the 166 authors of the 12 books published in the UK or the USA, only 75 lived in the post-socialist region, and only one of these books had an editor from outside of the Anglo-American sphere. Only in four cases were contributors from Eastern Europe in the majority, and two books were written exclusively by authors from the West. It would be highly instructive to draw up a list of all those who have become "experts on post-socialism" in this manner and who were commissioned to review pieces submitted to leading journals at the expense of their Central and Eastern European colleagues with a working knowledge of English. Realising the awkwardness of the situation, Bassnett from the UK, published a paper in 1992 with the title "How I became an Expert on East European Women Overnight". She described one of the major negative impacts of hegemony as follows :

Today, the terminology of rebirth, of helping, of educating the new democracies is all around us ; Poland, Czechoslovakia, Romania, and a whole host of other nations that were blank spaces on the map to most Westerners until very recently are now discussed in the classic language of the colonizer, the parental figure who

"discovers" a new land and finds the natives to be childlike creatures who need to be civilized (Bassnett, 1992, p. 11).

As to East-West joint projects, although there are a few good examples, they are based mostly on the inequality present in "Western (basically Anglo-American) theoriesEastern empirical studies" scenario. One of the greatest dangers that such imbalanced 
co-operation poses to the development of human geography (and hence to geography of gender) is that it may also contribute to the preservation of the already dominant empiricism and delay the launch of the process of working out theories that are valid for the circumstances in this region and able to interpret post-socialist transitions. It should be borne in mind that inequalities in this type of co-operation currently arise primarily from the fact that joint projects are either financed by the West European party or have a West European party as the lead partner, with more promising opportunities, more extensive practice, a professional institutional background and better connections. With the prospect of further EU enlargement, such power relations can easily lead to a similar hegemony in the post-socialist regions as well. The countries that have become EU member states recently may play a more dominant role in EU projects than the acceding ones.

\section{Differences/inequalities between Eastern and Western feminisms}

When discussing the forms of hegemony, we should take into account a rather unique debate on feminism after the political changes in 1989 and 1990, which can also affect the development of feminist geography. The differences (most acutely felt and clashing on a daily basis in the unified Germany) between Eastern and Western feminisms alone need not necessarily imply inequalities. The fact that they do is because the East has been incorporated into the West. Drakuliæ (in Funk, 1993) from Zagreb suggests that it is the real structural power and economic imbalances that are to blame for conflicts between women in the East and the West. Conversely, Funk (1993) in New York highlights power imbalances at the level of discourse and the hegemony of a Western feminist discourse, acknowledging the fact that this hegemony overrides postcommunist women's concerns that Westerners often raise inappropriate issues for Easterners to address (for example, editors assign authors to deal with particular issues). Discourses from both sides are full of stereotypes "of American and Western feminists as 'man-haters' or of post-communist women as simply having bought into sexism and having subordinated themselves to the family" (Funk, 1993, p. 320). However, offering an opinion of the relations that they have with each other, women in East Europe frequently regard Western feminists as "proselytisers: messianic, implicitly universalising, and thus imperialistic" (Gal, 1997, p. 89). Western feminists often find Eastern women "politically undeveloped, backward and ignorant in their rejection of western feminism, and sometimes simply apolitical" (Gal, 1997, p. 89). Some scholars also point out that, on the one hand, there are several types of feminism in both regions and, on the other hand, too much emphasis on differences may easily compromise the importance of identifying shared interests (for example, Bassnett, 1992; Gal, 1997). A good example of a dialogue on an equal footing is "From dictatorship to democracy : women in the Mediterranean, Central and Eastern Europe", a conference held in Barcelona in 1993.

\section{Attitudes towards hegemony in international feminist geographies}

East Central European researchers interested in the field of gender and geography also specialise in other areas of geography, thus they can face all the disadvantages listed above that arise from power relations. Yet, I hope that not just I, but others also have more encouraging experiences while carrying out gender studies. "Imported" partly 
from the West, the USA and UK, in particular, the field of gender and geography was in the making in this region in the early 1990s, at a time when feminist geography in the West began disseminating the notion of "situated knowledge". Adopting this approach, it also performed introspection, leaving no doubt that "place matters in the national/ regional development of feminist geography as well (Monk, 1994; Garcia-Ramon \& Caballé, 1998). The operation of the Commission on Gender and Geography of the International Geographical Union (establishing a good network, issuing newsletters and organising conferences) and the special issues of some journals (such as Geoforum, 1993/1, Journal of Geography in Higher Education, 2004/1) in which researchers from the post-socialist region were proposed as authors, were already part of a political action seeking to change the Anglo-American hegemony. Similar activities have helped us East Central Europeans cope with the negative feeling of "otherness" which stemmed from the fact that the knowledge we produce is different from its AngloAmerican counterpart. They have also helped us realise that it is not only in the postsocialist region that empiricism rather than theory dominates gender and geography (but also in developing countries), that gender studies on rural rather than urban areas/issues are more common (for example, in Spain, too) or that feminist geography serves spatial planning (as in the Netherlands).

From an East Central European perspective, the acceptance of diversity/difference in the field of gender and geography is higher than in mainstream geography. This, however, cannot resolve the problems arising from inequalities in access to publication (and often publications themselves), the hegemony of the English language, the dictates of Anglo-American theories and reviewers. Yet, if I say both difference and equality in our knowledge production should be jointly validated, I immediately encounter a classic dilemma of feminism with which Anglo-American feminist geography is imbued, that is, a mode of thinking that perceives equality and difference as opposing phenomena. Three epistemological perspectives advanced by McDowell (1993a) in my view suggest a "reluctant choice" between difference and equality. The three perspectives are rationalist or empiricist feminism, anti-rational or feminist standpoint theory and post-rational or post-modern feminism. While she associates the first with modernist tradition with its belief in rationality and equity, the second uses the valorisation of gender difference in order to set the category of feminist knowledge apart. "From the anti-rationalist perspective, the vision of equality that imbues work in the empiricist or rationalist mode - the sameness with men that appears to be being sought - is rejected as a gendered, masculinist version that denies the differences between women and men" (McDowell, 1993a, p. 306). In providing a summary of the interpretation of difference by feminist geography, Jackson, citing Young (1990, in Jackson, 2000, p. 175), asks "whether it is possible to have a respect for difference while maintaining a commitment to equality". Obviously, a dualist interpretation of the highly popular class and identity politics, it is not. The reason for this is that, according to this interpretation, class politics aimed at redistributive justice "tends to undermine group differentiation", while identity politics promotes it (Pratt, 2000, p. 368). East Central European experience has taught us a sad lesson as to the "results" of state socialist policy which advocated equality without accepting differences. Not even equality was forthcoming, however. A well-known symbol of equality that was expected to arise from sameness is a girl in overalls driving a tractor. In 1989 and 1990, those living in this region found themselves in a "post-modern Europe" that advocated multiculturalism and diversity, and where capitalism unleashed unprecedented 
inequalities. Neither equality, nor difference work well without the other, and if one is achieved, it does not follow that the other is as well. Hence I am convinced that the Anglo-American or Western hegemony of knowledge production will not cease to exist just by safeguarding diversity. Identity politics by itself is not enough; redistributive politics is also necessary. This is undoubtedly the case for those who do not have access even to the journals in which they could publish in several languages, not just case studies and not just papers reviewed by UK or US editors.

\section{The issue of difference : characteristics of the geography of gender in east central Europe}

\section{Symptoms and causes of marginalisation}

14 In her international overview in the early 1990s, Monk (1994) identified, in addition to Latin America, East Asia and a few West European countries (for example, France and Belgium), Eastern Europe and the Commonwealth of Independent States as regions where, although geography as a discipline is quite strong, feminist geography has very low visibility. If there is one shared feature of post-socialist countries that I would be able to describe without having to conduct a consistent international survey, it is the still low visibility of geography of gender/feminist geography ${ }^{3}$. It may well be the case that inadequate knowledge of the languages in the region, the relationships that are much looser between the countries here than they used to be and the scanty information due to lack of proper access to literature combine to create such a negative perception. Paradoxically, in a certain sense, I can rely on the vicarious help of at least a dozen geographers in the West whose papers, published in Anglo-American countries and hence more easily available for many ${ }^{4}$, clearly outline a feminist geography with East Central Europe as their subject matter (even if it is not a feminist geography of East Central Europe). It seems, however, that their references to papers on the postsocialist region are also references to papers by mostly Western authors cultivating other areas of social sciences. Thus, we come full circle. There may, of course, be more geographers in several East Central European ${ }^{5}$ countries than the eight to ten geographers (or researchers adopting a geographic approach) of the five countries on the basis of whose work I seek to provide a few general characteristics of the region's feminist geography. Such a small number, even if the numbers are an underestimation, suggests so little representation that the lack of feminist geography in East Central Europe or a time lag in its emergence should be thoroughly analysed not only because of its "otherness", but also because strong marginalisation in national geographies should warrant, more than in an average situation, the strengthening of international relationships on an equal footing along shared interests.

In order to better illustrate the marginalised status of feminist geography, I would like to provide a few more data. According to an international survey by Voiculescu and Lelea (2003), except for a course that they launched at Timisoara West University in October 2004, gender and geography as a course in East Central Europe was only available at Selye János University in Komarno, Slovakia and the Central European University in Budapest, Hungary. As regards universities in Komarno and Budapest : the plans for Komarno in 2006 failed $^{6}$, while the current curricula in Budapest, with geographer Regulska having resigned from her chair, refers to the aspect of space and 
place only in two courses on gender studies run by sociologists. Geographers are rarely cited as authors of compulsory reading even, for example, on "migration". Although one university textbook with one chapter devoted to feminist geography (Timár, 1998) is available in Hungary, only two institutions of higher education offer it as a theme (with tutorials held only once a semester).

We can hardly speak of an established practice of mainstreaming gender into diverse subfields in the discipline in East Central Europe. Some of the above researchers have published only one or two articles on gender since the 1990s. None cultivates it as the main area of research. In addition, we do not always seem to be, and in fact, we rarely are, consistent in highlighting gender aspects while addressing other issues. To varying degrees, subject to age and position, most of us experience seeking recognition for our gender studies and feminism as a source of strife in the academia. One of the signs of compromises, made willy-nilly, is that most papers painstakingly avoid the use of the word "feminist", abiding by the social attitude referred to many, among them Gal (1997, p. 91), who sums it up as follows, "feminism has largely remained a dirty word in the region, even an object of ridicule". This in turn confirms the assumption that the social and political context is as important an aspect as the institutional one if the root causes of the lack or strong marginalisation of the geography of gender/feminist geography are to be identified.

The defining role that the social context plays is underpinned by the fact alone that, in the 1970s and 1980s, when feminist geography started to gain ground in both advanced capitalist countries and several developing ones (and it even became professionalized in some), the whole of East Central Europe, heterogeneous from a number of aspects, remained unaffected by such changes. To what extent was the state socialist regime, the most important "common denominator" in the region, to be blamed for this?

According to Marxist ideology, which dominated the political discourse in the region for four decades, the end of class society also means the end of women's exploitation. As a first step, formal legal rights were unified in order to achieve the objective of "emancipation". Undoubtedly, there was also improvement in equal access to schooling, higher education, in particular. Most importantly, emancipation was expected to emerge as a result of large-scale female employment. However, the region's 80-90 per cent female employment rate would not have been possible without the provision of subsidised services, especially the establishment of a network of institutions, mainly kindergartens, providing childcare. In order to evaluate and sum up the results of the above measures and make them easy for the West to interpret, Ferge (1999), citing the gender division of economy and power, used Lewis's (1992, in Ferge, 1999) welfare state models7. She found that, of the "strong", "modified" and "weak" breadwinner states, "from a bird's eye view", the Eastern socialist bloc had borne the closest resemblance to the third. Although Lewis (1992, in Ferge, 1999) also points out that it is not only striving for gender equality that characterises the weak breadwinner model, Ferge (1999, p. 16) argues that "despite formal resemblances, the dimensions of liberalism and emancipation of the Scandinavian model were completely missing from the state socialist model". Many of the retrospective studies published after the regime change, especially the ones by "Eastern authors", went as far as also targeting the political attitudes underlying the measures of the socialist state. Šiklová (1993, p. 75) claims that socialist countries followed "their own interests in state and political power" rather than the original tenets of Marxism. While many talked of 
women being treated as a "reserve army" in the world of paid work, Heitlinger (1993) pointed out the explicitly demographic objectives for the attainment of which services, formerly organised on egalitarian grounds, were further developed in Czechoslovakia in the 1960s. By contrast, Ceausescu resorted to expressly coercive measures in Romania (see Hausleitner, 1993). According to Ferge (1999), in the era of totalitarian socialism, the party state did not think that the adoption of a consistently left-wing family or gender policy was necessary. The civil society, if there had been one, would not have been allowed to address this issue. Although several existing problems (for example, the skewed structure of the educational system, an increasingly low number of women in leading party positions and high-ranking jobs, lower pay, segregation in employment and problems arising from a double burden) belied the full implementation of declared equality, only the uncovering of the "unchallengeable" political intentions underlying these problems would have been able to render criticism levelled at these social problems credible. This was a hostile climate for feminist movements to evolve in. Some said it was not gender inequality that was held in the highest esteem anyway. Speaking of the Bulgarian society, Slabakova (1992, p. 140, in Łobodziñska, 1995a), for instance, claims that it "was not so much maleoriented as Communist party-oriented“. By contrast, Ferge (1999) considered the refusal of spontaneous movements by anti-liberalism as well as the anti-solidarity and anti-party identity attitude of the totalitarian regime to be the biggest obstacle to the evolution of feminist movements. Feminist movements cannot evolve without the recognition of collective wrongs. Under the harsh conditions of state socialism, it was impossible for such recognition to occur. (Neményi, 1994 ; Ferge, 1999).

Feminist movements, key to the birth of feminist geography in the West, were thus missing in East Central Europe, and female geographers also failed to recognise their own marginalised status in academia. The discipline of geography was unable to be seminal to the evolution of women studies/gender studies even to the extent that, for instance, sociology - which managed to notch up a few non-state commissioned papers analysing, among other things, women's status - was able to in certain parts of the region in the 1970s and mostly in the $1980 \mathrm{~s}^{8}$. What were the special factors characterising geography that hindered the development of gender and geography as a field and of a feminist approach?

In following a train of thoughts that enables me to provide an answer to this question, I must draw primarily on my experience in Hungary. The reason for this is that the status of geography reflected a more subtle picture than what would have followed from the national differences in curtailed freedom in the socialist era. Undoubtedly, the role of established geography was different in Romania, where, according to Voiculescu and Lelea (2003, p. 136) "social geography was restricted to statistics convenient to the dictatorship", from that in Poland, where geography, which earned international recognition in some subfields boasted of the best relationships with the West in the Soviet bloc. In Hungary, following the Soviet model, human geography was also replaced with economic geography. Population and settlement geography was mostly embedded in or linked to the latter for a long time. Western experience confirms that economic geography itself is not necessarily a hindrance to research on women. But when the social processes of work are taken to be the equivalent of economic production, an entire human aspect of human geography falls away. When, as in Hungarian economic geography during socialism, economic production is taken to be the responsibility of women as much as men, the resulting geographical literature is 
essentially gender-blind. To make things worse, research treated both women and men as a genderless "labour force". As a result, all "human" geography becomes genderblind. In contrast to Western geography, where "Economic Man" played such a central role, gender-blindness in Hungarian geography did not always mean that a malecentred social model was being universalised. This economic geography therefore posed less of an immediate provocation to feminists (if there were or had been any at all); it abstracted not just from women but also from humanity in general. In population geography, differences in gender composition or, for example, male and female migration statistics were, at best, recorded, but treated as descriptive results rather than social causes, or symptoms of deeper social problems. In Hungary, state censorship was less severe than in Romania, where research on social problems was not permitted at all (Voiculescu \& Lelea, 2003). Nevertheless, sociologists carrying out research on, among other things, poverty encountered conflicts with the establishment of the time in Hungary as well. In the 1970s, the findings of settlement and mainly rural geography, which had already succeeded in identifying socio-spatial inequalities, looked "harmless" to the regime because of a conservative perception of space that they reflected ${ }^{9}$; however, for the same reason, they could not lead even to a fledgling feminist geography. Furthermore, like several other geographies in East Central Europe, Hungarian "human" geography was an extremely closed discipline (Beluszky, 1989). Not only did it fail to provide an entrée for Western feminist work, but it also remained unaffected by those results of domestic urban sociology that now began to appear in print and could have served as an impetus for feminist writings similarly to Anglo-American experience.

21 A further, even graver problem was that there were no thought-provoking scientific debates on social theories or geographical "paradigms". Social theories themselves were missing from geography, because - as in other countries in the region - it was not advisable to identify with philosophical approaches different from a narrow statesponsored version of Marxism. One could say that when feminist geography began to develop in the English-speaking world in the early 1970s, it was closely interrelated with emerging radical and Marxist critiques of geographical orthodoxy (Pratt, 2000). In Hungary, and elsewhere in East-Central Europe, where a form of Marxism was state ideology, feminism from the start would have had to differentiate itself radically from this form of orthodoxy. Marxism focused on questions of the reproduction of capital and class struggle in capitalist societies ; by contrast, "officially", neither existed under the socialist state, and thus Marxism was hardly able to be an effective critical tool - for either feminism or any other social opposition.

I hope the foregoing has been able to provide an insight into why feminist geography was non-existent in East Central Europe, where the logic of totalitarianism refused to give a go-ahead to feminism and strengthened the positivist nature of geography, thus making it unsuitable, from the outset, for "reception". It may also have been able to shed light on why epistemological issues were different from those in Western geographies in terms of both content and manner. However, 15 years after the political changes Hanson's (1992, p. 569) question, asked originally in a Anglo-American context, has become truly topical, though only a "negative version" of it. "Geography and Feminism: Worlds in Collision?" should be replaced with why is collision still late materialising? 
Although the diversity and varying depth of post-socialist transitions further increased heterogeneity in East Central Europe, some of the changes that influenced the development of feminist geography can be summed up with general relevance as follows :

- With the emergence of the market economy, both ownership relations and the principles underlying the operation of the economy have been approximating to those in the Western world. Uneven development, typical of capitalism, has become a fact of life in this region as well. Social polarisation has increased and the patriarchal nature of the society has become obvious. Undoubtedly, as elsewhere in the advanced capitalist world, in this region, too, there has arisen the need for understanding social transformation, gender inequalities and differences among women, and so on, and the feminist approach-based production of geographical knowledge.

- The new democratic order grants the freedom that allows for the possibility that various (among them gender) identities can be recognised. It also grants the freedom of opinion and association, hence the establishment of civil associations, as well as the freedom of choice from among social theories. Women's organisations also started to develop, though the extent of development varied from one country to the next. It is true that a negative social attitude towards feminism prevails. While the latter dampens interest in gender studies, the former boosts it.

- The transformation of the institutional system of geography has commenced. Western patterns have started to replace their Russian counterparts in a number of ways (for example, in the introduction of subdisciplines that were not previously cultivated). However, the reception and recognition of progressive social theories and, most importantly, the feminist approach has proven to be very slow.

It seems that transition in geography lags considerably behind political, economic and even social transition, which is much slower than the first two. What follows identifies the characteristics of positivism in human geography that interfere with feminist geography.

\section{Topical and geographical focuses : the causes of differences from the Anglo-American tradition}

"Because the field is relatively small, the role of individuals is quite important..." If Monk (1994, p. 279), profiling feminist geography at an international scale, thought she should make this remark, the relative importance of the individuals in a small group whose research on gender and geography I rely on in exploring East Central European characteristics is bound to be even greater. And all this at a time when international feminist geography is likely to be able to exert a tangible impact on knowledge production in the region. That, for instance, studying and obtaining a $\mathrm{PhD}$ degree abroad is of key importance and may even be conducive to the emergence of feminist geography, is illustrated by some examples in a post-socialist Europe as well, similarly to Taiwan, India or Korea (see Rii, 1993). Nevertheless, the significance of the national (historical, geopolitical, cultural and institutional) context is confirmed by the fact that an "imported" field does not necessarily simply follow the path of development that the field did in its country of origin.

It was not common at all, for instance, for "the issue of the invisibility of women, both as the subjects of geographical study and as practitioners of the discipline ${ }^{10}$ (Bowlby et 
al., 1989) to serve as a starting point in East Central Europe, as had been the case in the Anglo-American practice. Judging from the papers by the authors that I know, only in 2003 and 2004 were papers analysing women's representation in the discipline published, in part or in whole (Voiculescu \& Lelea, 2003 ; Timár \& Fábián Jelenszkyné, 2004), despite the fact that in Hungary, similarly to Catalonia (see in Garcia-Ramon \& Pujol, 2004), representation appeared to be decreasing ${ }^{11}$. My own personal experience ${ }^{12}$ also illustrates the extent to which an inherited low level of identity as women outlined in the previous section and a negative social attitude towards feminism are responsible for the time lag referred to above. Only in 1990, after I had graduated from university and spent several years in employment in Hungary, and while I was discovering feminist geography for myself in the USA, did I face for the first time the disadvantages of a male-dominated Hungarian geography in my academic career and the nature of such disadvantages. It took a decade after the publication of my first paper on gender and geography in 1993 for me to analyse the issue of representation of women, and even then it was a paper commissioned abroad.

From the outset, the main objective has been making both gender and women as subjects of geographical study visible. No one could gainsay that the results evoke the "geography of women", that is, first era or strand of the Anglo-American feminist geography (Bowlby et al., 1989; Pratt, 2000), because we are mainly witnessing the documentation of gender inequalities. As attention is focused on the issue of gender roles, however, so does interest in gender relations increase. Likewise, the first attempts at providing an explanation for the relationship between post-socialism and patriarchy can also be identified. Thus, there are signs of the presence of a "socialist feminist geography" strand (that is, the second era) as it is called in the AngloAmerican terminology. One thing is sure, however, that is that, in contrast to the Anglo-American experience, the direct impact of neither the critique of Marxism, nor of liberal or socialist feminism is discernible in publications in East Central Europe. Even if there is such an impact, the authors fail to point this out.

What all "feminist geographers" focus on is the relationship between gender and postsocialist transition. The importance of the topic is underscored by the fact that Western geographers studying gender issues in East Central Europe also analyse these same issues even if their approach, degree of conceptualisation, methods and rhetoric are significantly different. Researchers in East Central Europe often describe spatial differences in women's status in relation to men's as well as gender inequalities as "losers and winners". In this region, however, women's situation compared to what it was in their own socialist past is as important an aspect of being a loser as their position compared to men's. In addition to highlighting the gendered nature of transition, feminist geographers keep emphasising the presence of inequalities along class relations by pointing out unprecedented high female unemployment, economic inactivity (Ciechociñska, 1993 ; Timár \& Velkey, 1998; Gerasymenko, 2002 ; Váradi, 2005 ) and the feminisation of poverty (Rochovská, 2005). However, their description of women as losers does not merit the same criticism as is voiced against the "passive victim" approach in the Anglo-American geography (Foord \& Gregson, 1986, in Pratt, 2000). The reason for this is that, among other things, feminist geography, at least in Hungary, pioneered in changing the "human blind" nature of East Central European geography through doing research from the perspective of active agents and individual decisions. Topics such as the gendered survival strategies of households (Timár, 2001), the decisions of the new participants, (among them women entrepreneurs), in an 
increasingly market economy (Szörényiné Kukorelli, 1999; Momsen \& Szörényiné Kukorelli, 2002 ; Momsen et al., 2005) or the transformed lives of former miners' wives, who are in a completely different situation relative to earlier circumstances (Jelenszkyné Fábián, 2001), are not merely new topics for a new era. Rather, they have been instrumental in feminist geography's being able to exert its most important impact on mainstream geography. It has introduced several qualitative methods, e.g. life-course interviews and focus groups, which are missing from the methods of even social geography following the pattern of the German school of thought or a fledgling behavioural geography.

The primary importance of post-socialist transition as a central topic is underpinned by the fact that geographical research addresses the issue of gender relations in society in the context of two main trends in the era: the evolution of capitalist conditions (economic transition) and democratisation (political transition). Although, for lack of a satisfactory amount of data, no accurate conclusion can be offered, I find that geographers in East Central Europe, despite a shift relative to mainstream geography, are interested in paid rather than domestic work, the structural characteristics of the labour market rather than women's (and men's) labour market experience, thus, overall, the public rather than the private sphere ${ }^{13}$. The opposite is the case in Western feminist geography studying the region ${ }^{14}$. It should be borne in mind, however, that the meaning of "public/private" is in part different in East Central Europe from what it means in the West. In the era of post-socialist transition, privatisation accords special importance to the public-private relationship in the economy. This is indeed why research on women entrepreneurs referred to above within the framework of research on the private sector is so important in both feminist geography and sociology. A legacy from the socialist past, another significant dimension of the public-private relationship is the relationship between the state and the family. The family used to be a haven where one could be safe from the omnipresent control of a paternalistic socialist state, it was, for example. a "substitute arena for activities that in the West might be found in the public sphere", such as the safe discussion of political issues (Funk, 1993, p. 323). Ferge (1999) claims that while state socialism improved women's situation in a number of respects, it hardly affected the manner in which the traditional male and female roles evolve in the family, that is, in the private sphere. The contribution of feminist geography to current sociological research on this topic ${ }^{15}$ includes its findings on the presence of patriarchy at a national, local and household scale and the fact that, as regards the adjustment of households to transition, the village - especially in economically disadvantaged areas - seems to foster traditional gender roles (Momsen et al., 2005; Timár, 2005). The latter reflects the issue of reconciling domestic work with paid work, a problem that faced a large number of women already in the era of state socialism, and that of the relationship between the public and the private as "double burden" ${ }^{16}$, which raises further issues, given the fact that the provision and maintenance of childcare institutions is no longer a priority for the state (Ciechociñska, 1993) ${ }^{17}$. The public-private relationship is less visible in the studies on women's political participation (Timár, 2004b). Geographers mainly record the fact that women have left the scene of national politics. They are less interested in a similar phenomenon in local politics (Timár, 2000, 2004b; Gerasymenko, 2002). A striking difference between them and their Western feminist counterparts doing research on East Central Europe is that the latter focus mainly on local democracy and formal and informal political life (see e.g. Regulska, 1994 ; Graham \& Regulska, 1997 ; 
Iganski, 1999; van Hoven, 2002). These conceptual and methodological differences, however, lead us to more general epistemological issues.

Besides its priority of topics, feminist geography/geography of gender in East Central Europe has at least four characteristics that are different from those of its AngloAmerican counterpart :

- Of space, place and nature, the three fundamental concepts of the discipline, feminist geography focuses on the first, i.e. the spatial differences of women's status and gender inequalities. As a response in part to the challenges of European regionalisation, it accords primary importance to the regional scale. It is mainly researchers "on the borderline" of geography, sociology and anthropology (see, for example, Kovács \& Váradi, 1997; Schawarcz, 2004) who excel in analysing the gender-place relationship, which is subordinate as a topic to space - a further difference from the Western geography studying the region. For the time being, nature is still a terra incognita in feminist geographic research in East Central Europe. Finally, it covers rural rather than urban areas.

- It prioritises gendered social relations in the "real" material world over gender symbolism (see in McDowell, 1993b). In contrast to Western scholars, who have chosen East Central Europe as the subject matter of their research, the geography of the body (Voiculescu, 2004) and that of gendered identity are uncommon in East Central Europe.

- Feminist geography in East Central Europe has an empirical emphasis ; it is more descriptive than theoretical.

- From several aspects, this geography is rooted in the old/new traditions of applied research, which has gained currency in the region.

Since, of the four characteristics, the first three also characterised, to a varying extent, the initial period of the Anglo-American feminism (see McDowell, 1993b), we may easily arrive at the conclusion that we are witnessing a "time lag" rather than material differences. The circumstances, both those facilitating and the ones blocking further development are, however, only in part similar to the Anglo-American context. Moreover, criticism levelled at the current situation (that is characteristics) has also given rise to the consideration of values and aspects other than the ones that were seminal to the emergence of a new era/strand of "feminist geographies of gender" in the Anglo-American context (McDowell, 1993a ; Pratt, 2000) :

The most important problem is that conservatism and positivism prevail in mainstream geography, with only the mapping of spatial patterns allowed to be included in the concept of "absolute space", which is considered to be a container, "predominantly empty until filled with objects and events" (Smith, 2000, p. 487). To make things worse, such mapping is of quantitative nature. It rarely adopts the qualitative methods that are so important for feminist geography. "Body" and "identity" are considered to be as alien to the discipline in an institutional context where Voiculescu \& Lelea (2003, p. 138) faced the following problem when they first ran a university course in gender and geography in Romania : At first the students were very sceptical as to how gender can be part of geography. In order to build on familiar terrain, the course started with maps of indicators relevant to gender by nation-state..." Making adjustments to the recent concept and image of geography, and similarly to Voiculescu and Lelea (2003), many strive to "prove" to mainstream geography and co-disciplines that the existence of feminist geography is perfectly "justified" by using the traditional approach and methods (mapping). There has been no shift away from objectivist epistemologies: relativism and situated knowledge have not gained ground yet (they may not even have 
been introduced in some countries). As yet, social and cultural theories as fomentors have been unable to penetrate into established geography. Nor has critical geography, which can provide support for feminist geography, been able to gain in popularity in part for the same reasons and in part because of the negative connotation associated with left-wing thinking in the post-socialist part of Europe.

Nevertheless, there is social need in East Central Europe for empiricism on the "real" material world and not only for the same reason as in Anglo-American geography at a time when it was necessary to gain recognition for feminist work. The post-socialist transition is a new era with processes the trends and laws of which have been unknown to us. For the time being, the documenting and mapping of gender and other old/new differences and inequalities alone is a topical issue. (It should be admitted, though, that providing an explanation for them would also be important.) Furthermore, it is worth considering whether Raju's (2002) assertion, the geography of body "is an academic luxury that we from the 'Third World' cannot afford", made in defence of feminist geography in India, which is different from its Anglo-American counterpart, also applies to East Central Europe. Judging from Voiculescu's study (2004), it definitely cannot apply to Romania, which has just disentangled itself from Ceausescu's dictatorship and stringent laws on abortion and homosexuality. It is an unchallengeable fact, however, that public debate in East Central Europe also grants priority to the implications (class inequalities and poverty) of uneven development, further aggravated by new capitalism, over the problems arising from gender-, raceand sexual orientation-based oppression. A Western geographer, Brunell (2005, p. 303), researching domestic violence policy in Poland, offers the following opinion of this, that is, priorities, "It is unlikely that a rural municipality faced with the prospect of closing its schools will find the resources to provide domestic violence services or even the resources necessary to transport women to a jurisdiction that does provide them".

Finally, the need for applied research also lends itself to different interpretations. The EU regional planning seems to have replaced central planning in state socialism in providing assignments for applied geography, which, given the financial constraints of academic institutions, needs such assignments. The integration of feminist geography in this practice may enable it to prove its "usefulness" for mainstream geography (see, for example, G.Fekete, 2004; Bucher \& Jelenszkyné Fábián, 2006). Furthermore, the EU's gender mainstreaming policy itself justifies the existence of the gender issue at least for those who seek financing support for their development projects. The question remains whom/what applied research serves, since its traditional version, as generated by mainstream geography, reinforces the status quo (Harvey, 1984). Perhaps, this is where feminist geography will be able to achieve the most rapid breakthrough in East Central Europe. This is all the more likely, because feminist geography, at least in Hungary, has been associated with fledgling women's organisations and has been developed in accordance with the needs of such organisations, in the interest of and together with women. In this respect, feminist geography in East Central Europe is likely to have either bridged a "gap of 20 years" or channelled development in a very "special" new direction. 


\section{Conclusions}

Undoubtedly, despite the inner heterogeneity of the region, feminist geography in East Central Europe exhibits characteristics that set it apart from its Anglo-American (or, as far as certain characteristics are concerned, "Western") counterpart. I agree with those who claim that we cannot be content with merely identifying these differences. Similarly to those who - in connection with Anglo-American research based on the "feminist geography of difference" approach - pointed out that "boundless difference" carried risks (see Pratt, 2000), or like Katz (1998, p. 258.), who - referring to an unhealthy diversity of critical geography - suggested that it should be decided as to "which differences matter when", we should also make a similar decision with regard to our own academic life. In making such a decision, I can only voice my opinion, no one else's. Living in Europe's post-socialist part, I am convinced that, of regional characteristics, it is mostly the late evolution and long-protracted development of feminist geography that "matters". This difference is also the outcome of serious inequalities, the kind of difference that should be addressed through the transformational (deconstructive) approach of class politics rather than the affirmative approach of identity politics (Fraser, 1997, in Pratt, 2000).

It looks as if this problem should and could be resolved in East Central Europe. Those who live here must fight against their own national mainstream geography, with the lack of their own feminist consciousness being their greatest adversary in some cases. However, they get immense help from feminist geographies outside the region, for example, from Anglo-American feminist geography that offers lessons to be learned. The "central marginality" position, in McDowell's interpretation (1993), of AngloAmerican feminist geography, which evolved in the post-colonialist, post-structuralist worlds of the 90s, is equally helpful ${ }^{18}$. For us, East Central Europeans, the recognition that feminist geography has earned and that is reflected in "international" (that is, Anglo-American) journals is an important point of reference - at least in those countries in East Central Europe where such journals are available. The results that were born in those parts of the world where feminist geographies (empirical, rural focus, connection to planning and women's association, and so on) have much more in common with their East Central European counterparts could be of at least as much help. However, Anglo-American hegemony hampers their becoming public knowledge. It also hampers the publication of papers by authors from the post-socialist region in international journals. Thus, such hegemonic relations also matter. Thus, if we can do something to alleviate these inequalities, e.g., by organising conferences or conducting balanced joint projects, it benefit us all. It is mainly our academic career that could benefit from them. However, what about those outside the academic world?

When running a graduate course in gender and geography for the first time, Voiculescu and Lelea (2003, p. 139) chose topics that could "connect the academia with the society outside", hoping that they could urge students to continue research and involvement in gender related problems of Romania. Examining the utility of theory and theoretical languages in transnational feminist praxis, Nagar (2002, p.179) claims that it is important to provide an answer to the question of "who are we writing for, how and why?" The answers to this question will inevitably be manifold, depending on the researchers ranging from those who seek "alternative futures through implicit means such as raising consciousness" and those who seek "research strategies that will 
empower their research subjects" to those who explicitly seek "change through their own political and social actions" (Kitchin, 1999, p. 225). Whichever we accept as an answer, we should understand not only at the local but also at the global scale how gender relations and geographies are mutually structured and transformed. This presupposes mutual interests, i.e. the usefulness of the knowledge that Europe's post socialist part can offer. As Bassnett (1992, p. 15) puts it, "As we slowly begin to discover more about women in Eastern Europe, we may hopefully discover more about ourselves". A way of thinking like this is instrumental in deconstructing East-West South-North etc., differences, even if it cannot discontinue the geopolitical and economic dichotomy that underlies such differences.

\section{BIBLIOGRAPHY}

ASHWIN S. (2002), “'A women is everything' : the reproduction of Soviet ideals of womanhood in post-communist Russia“, in RAINNIE A, SMITH A. \& SWAIN A. (eds.) Work, Employment and Transition : Restructuring livelihoods in post-communism, London and New York, Routledge, pp. 117-133.

BASSNETT S. (1992), “Crossing Cultural Boundaries : Or How I Became and Expert on East European Women Overnight“, Women's Studies International Forum, 15 (1), pp. 11-15.

BELUSZKY P. (1989), “Magánjelentés a (társadalom)földrajzról“, Tér és Társadalom, 1, pp. 49-63.

BERG L. D. \& KEARNS R. A. (1998), “America unlimited“, Environment and Planning D : Society and Space, 16, pp. 128-132.

BOWLBY S., LEWIS J., MCDOWELL L. \& FOORD J. (1989), “The geography of gender", in PEET R. \& THRIFT N. (eds.) New Models in Geography, vol. 2, London, Unwin Hyman, pp. 157-175.

BRUNNEL L. (2005), "Marginality and the New Geography of Domestic Violence Policy in PostCommunist Poland", Gender, Place and Culture, 12 (3), pp. 293-316.

BUCHER E. \& JELENSZKYNÉ FÁBIÁN I. (2006), “A Pécsi kistérség nonprofit szférájának gender alapú elemzése“, Földrajzi Értesítõ, 1-2, in print.

CIECHOCIÑSKA M. (1993), "Gender Aspects of Dismantling the Command Economy in Eastern Europe : the Polish Case“, Geoforum, 24 (1), pp. 31-44.

CORRIN C. (ed.) (1992), Superwomen and the Double Burden. Women's experience of change in central and eastern Europe and the former Soviet Union, Toronto, Second Story Press.

DUNCAN S. (1996), "The Diverse Worlds of European Patriarchy“, in GARCIA-RAMON M. D. \& MONK J. (eds.), Women of the European Union. The Politics of Work and Daily Life, London and New York, Routledge, pp. 74-110.

FEISCHMIDT M., MAGYARI-VINCZE E. \& ZENTAI V. (eds.) (1997), Women and Men in East European Transition, Cluj-Napoca, Editura Fundatiei Pentru Studii Europene. 
FERGE ZS. (1999), “Hogyan hatott a rendszerváltás a nõk helyzetére ?“, in LÉVAI K., KISS R. \& GYULAVÁRI T. (eds.), Vegyesváltó. Pillanatképek nõkrõl, férfiakró, Budapest, Egyenlõ Esélyek Alapítvány, pp. 13-29.

FUNK N. (1993), “Feminism East and West", in FUNK N. \& MUELLER M. (eds.), Gender Politics and Post-Communism. Reflections from Eastern Europe and the Former Soviet Union, New York and London, Routledge, pp. 318-330.

GAL S. (1997), "Feminism and Civil Society", in FEISCHMIDT M., MAGYARI-VINCZE E. \& ZENTAI V. (eds.), Women and Men in East European Transition, Cluj-Napoca, Editura Fundatiei Pentru Studii Europene, pp. 89-99.

GARCIA-RAMON M. D. \& CABALLÉ A. (1998), "Situating gender geographies : A bibliometrical analysis“, Tijdschrift voor Economische en Sociale Geografie, 89 (2), pp. 210-216.

GARCIA-RAMON M. D. \& PUJOL H. (2004), “Gender representation in academic geography in Catalonia (Spain) : Towards a masculinization of the discipline ?", Journal of Geography in Higher Education, 28 (1), pp. 111-120.

GERASYMENKO G. (2002), "Gender Geography of Political Life in Ukraine“, $3^{\text {rd }}$ International Conference of Critical Geography, Békéscsaba, Hungary June 25-30, Békéscsaba, International Critical Geography Group, pp. 85-89.

G.FEKETE É. (2004), A nõk a vidékfejlesztésben, Manuscrip, Miskolc, MTA RKK.

GRAHAM A. \& REGULSKA J. (1997), "Expanding political space for women in Poland : An analysis of three communities", Communist and Post-Communist Studies, 30 (1), pp. 65-82.

HANSON S. (1992), "Geography and feminism : worlds in collision?", The Annals of the AAG, 82 (4), pp. 569-586.

HARDY J. \& STENNING A. (2002), "Out with old, in with the new ? The changing experience of work for Polish women“, in RAINNIE A., SMITH A. \& SWAIN A. (eds.), Work, Employment and Transition : Restructuring livelihoods in post-communism, London and New York, Routledge, pp. 99-116.

HARVEY D. (1984), “On the history and present condition of geography : a historical materialist manifesto“, Professional Geographer, 36, pp. 1-11.

HAUSLEITNER M. (1993), "Women in Romania : Before and after the collapse“, in FUNK N. \& MUELLER M. (eds.), Gender Politics and Post-Communism. Reflections from Eastern Europe and the Former Soviet Union, New York and London, Routledge, pp. 53-61.

HEITLINGER A. (1993), "The impact of the transition of communism on the status of women in the Czech and Slovak Republics“, in FUNK N. \& MUELLER M. (eds.), Gender Politics and Post-Communism. Reflections from Eastern Europe and the Former Soviet Union, New York and London, Routledge, pp. 95-108.

HOVEN-IGANSKI B. VAN (2000), Made in GDR. The Changing Geographies of Women in the Post-Socialist Rural Society in Mecklenburg-Westpommerania, Nederlandse Geografische Studies 267, Utrecht/ Groningen, Koninklijk Nederlands Aardrijkskundig Genootschap/ Faculteit der Ruimtelijke Wetenschappen Rijksuniversiteit Groningen.

HOVEN B. VAN (2002), "Experiencing democracy : Women in rural East Germany", Social Politics, 9 (3), pp. 444-470.

HOVEN B. VAN \& PFAFFENBACH C. (2002), "Labour markets in transition. The experiences of women in two border regions of East Germany", GeoJournal, 56, pp. 261-269. 
HOVEN B. VAN (2003), “Women's lives in transition in rural East Germany“, Eastern European Countryside, 9, pp. 87-101.

HÖRSCHELMANN K. \& HOVEN B. VAN (2003), "Experiencing displacement : The transition of women's spaces in (former) Easy Germany“, Antipode, 35 (4), pp. 742-760.

IGANSKI B. (1999), “The meaning of women's 'second family' for current patterns of discontinuity in rural East Germany“, in COOKE P. \& GRIX J. (eds.), German Monitor. East German Continuity and Change, Amsterdam, Atlanta, GA, Rodopi, pp. 151-161.

JACKSON P. (2000), "Difference“, in JOHNSTON R. J., GREGORY D., PRATT, G. \& WATTS, M. (eds.) The Dictionary of Human Geography, $4^{\text {th }}$ Edition, Oxford, Blackwell, pp. 174-175.

JELENSZKYNÉ FÁBIÁN I. (2001), “Nemek és a földrajzi tudás avagy Kolombusz nem volt nõ, hogy hibáztatható lett volna az eltévedésért", in RAKONCZAI J. (ed.), A földrajz eredményei az új évezred küszöbén. A Magyar Földrajzi Konferencia közleményei, Szeged, SZTE TTK Természeti Földrajzi Tanszék, Szeged, CD.

KATZ C. (1998), "Lost and found in the posts : addressing critical human geography", Environment and Planning D, Society and Space, 16, pp. 257-278.

KITCHIN R. (1999), "Morals and ethics in geographical studies of disability", in PROCTOR J. D. \& SMITH D. M. (eds.) Geography and Ethics, London, Routledge, pp. 223-236.

KOVÁCS K. \& VÁRADI M. M. (1997), “Small town women“, The Hungaria Quarterly, 38, Autumn, pp. 78-90.

LELEA M. (2000), Women's Entrepreneurship in Rural Romania Bordering Hungary, Unpublished Honors thesis, Davis, University of California.

ŁOBODZIÑSKA B. (1995a), "Equal opportunities : Obstacles and remedies", in ŁOBODZIÑSKA B. (ed.), Family, Women, and Employment in Central-Eastern Europe, Westport, Connecticut \& London, Greenwood Press, pp. 261-274.

ŁOBODZIÑSKA B. (1995b), "The family and working women during and after socialist industrialization and ideology“, in ŁOBODZIÑSKA B. (ed.), Family, Women, and Employment in Central-Eastern Europe, Westport, Connecticut \& London, Greenwood Press, pp. 1-46.

ŁOBODZIÑSKA B. (ed.) (1995c), Family, Women, and Employment in Central-Eastern Europe, Westport, Connecticut \& London, Greenwood Press.

MCDOWELL L. (1993a), "Space, place and gender relations : Part 2. Identity, difference, feminist geometries and geographies", Progres in Human Geography, 17 (3), pp. 305-318.

McDOWELL L. (1993b), "Space, place and gender relations : Part 1. Feminist empiricism and geography of social relations“, Progress in Human Geography, 17 (2), 157-179.

MEUSBURGER P. (2001), "Spatial and social disparities in unemployment in Hungary", in MEUSBURGER P. \& JÖNS H. (eds.), The Transformations in Hungary : Essays in Economy and Society, Heidelberg-New York, Physica-Verlag, pp. 173-206.

MOMSEN J. H. \& SZÖRÉNYINÉ KUKORELLI I. (2002), “Gender and rural entrepreneurship in postcommunist east and west Hungary“, Eastern European Countryside, October, pp. 109-118.

MOMSEN J. H. with KUKORELLI SZÖRÉNYI I. \& TIMÁR J. (2005), Gender at the Border. Entrepreneurship in Rural Post-socialist Hungary, Burlington, Ashgate.

MONK J. (1994), “Place matters : Comparative international perspectives on feminist geography“, Professional Geographer, 46 (3), pp. 277-288. 
MONK J., DROOGLEVER FORTUIJN \& RALEIGH C. (2004), "The representation of women in academic geography : Contexts, climate and curricula“, Journal of Geography in Higher Education, 28 (1), pp. 83-90.

NAGAR R. (2002), "Footloose researchers, 'travelling' theories, and the politics of transnational feminist praxis“, Gender, Place, Culture, 9 (2), pp. 179-186.

NEMÉNYI M. (1994), “Miért nincs Magyarországon nõmozgalom ?", in HADAS M. (ed.), Férfiuralom - Irások nõkrõl, férfiakról, feminizmusról, Budapest, Replika Kör, pp. 235-245.

PERRONS D. \& GONÄS L. (1998), “Introduction : Perspectives on gender inequality in European employment", European Urban and Regional Studies, 5 (1), pp. 5-12.

PIGNICZKY R. (1997), “The making of a women's movement in Hungary after 1989“, in RENNE T. (ed.), Ana's Land. Sisterhood in Eastern Europe, Boulder and Oxford, WestviewPress, pp. 121-132.

PRATT G. (2000), “Identity politics“, in JOHNSTON R. J., GREGORY D., PRATT G. \& WATTS M. (eds.), The Dictionary of Human Geography, $4^{\text {th }}$ Edition, Oxford, Blackwell, pp. 367-369.

RAJU S. (2002), “We are different but can we talk ?", Gender, Place and Culture, 9 (2), pp. 173-178.

REGULSKA J. (1994), “Transition to local democracy“, in RUESCHEMEYER M. (ed.), Women in the Politics of Postcommunist Eastern Europe, Armonk, New York, London, M. E. Sharpe, Inc, pp. 35-62.

RII H. U. (1993), “II. Asia : Focus on Taiwan, India and Korea“, Working Paper 27 : Contextualising Feminist Geography : International Perspectives, IGU Commission on Gender and Geography, pp. 12-17.

ROCHOVSKÁ A. (2005), Vybrané Aspekty Chudoby na Slovensku s Bližším Zretel’om na ženy, Na získanie vedecko-akademickej hodnosti philosophiae doctor, Bratislava.

SCHWARCZ GY. (2004), “Leosztott szerepek, kitörési kísérletek“, in SÁFRÁNY R. (ed.), Életpályák és mozgásterek. Nõk a helyi közéletben, Budapest, MONA, pp. 49-65.

ŠIKLOVÁ J. (1993), “Are women in central and eastern Europe conservative ?“, in FUNK N. \& MUELLER (eds.), Gender Politics and Post-Communism. Reflections from Eastern Europe and the Former Soviet Union, New York and London, Routledge, pp. 74-83.

SMITH N. (2000), "Marxist geography“, in JOHNSTON R. J., GREGORY D. PRATT G. \& WATTS M. (eds.), The Dictionary of Human Geography, $4^{\text {th }}$ Edition, Oxford, Blackwell, pp. 485-492.

SZÖRÉNYINÉ KUKORELLI I. (1999), “A nõi egyéni vállalkozások néhány jellemzõje a határ mentén“, in NÁRAI M. \& RECHNITZER J. (eds.), Elválaszt és összeköt a határ. Társadalmi-gazdasági változások az osztrák-magyar határ menti térségekben, Pécs-Gyõr, MTA RKK.

TIMÁR J. (1998), “Feminista földrajz“, in TÓTH J. \& VUICS, T. (eds.), Általános társadalomföldrajz I., Budapest-Pécs, Dialog Campus, pp. 266-283.

TIMÁR J. \& VELKEY G. (1998), “The question marks of the relatively favourable rate of female unemployment in Hungary“, in BASSA L. \& KERTÉSZ L. (eds.), Windows on Hungarian Geography, Budapest, Geographical Research Institute HAS, pp. 199-209.

TIMÁR J. (2000), “Geographical aspects of changing conditions of women in post-socialist Hungary", in KOVÁCS Z. (ed.), Hungary Towards the $21^{\text {st }}$ Century. The Human Geography of Transition, Budapest, Geographical Research Institute HAS, pp. 151-167.

TIMÁR J. (2001), “A háztartási 'túlélési stratégiák’ területi szempontú kutatásának néhány elméleti kérdése és empirikus eredménye az átment idõszakában Magyarországon“, in EKÉNÉ ZAMÁRDI I. (ed.), Jubileumi tanulmányok, Debrecen, Debreceni Egyetem, pp. 209-218. 
TIMÁR J. (2002), "Restructuring labour markets on the frontier of the European Union : Gendered uneven development in Hungary“, in RAINNIE A. SMITH A. \& SWAIN A. (eds.), Work, Employment and Transition: Restructuring livelihoods in post-communism, London and New York, Routledge, pp. 134-154.

TIMÁR J. (2004a), “More than 'Anglo-American', it is 'Western' : hegemony in geography from a Hungarian perspective“, Geoforum, 35, pp. 533-538.

TIMÁR J. (2004b), “Gendered urban policy-making ; the role of geographical scale in women's participation in Hungarian local governments“, in CORTESI G., CRISTALDI F. \& DROOGLEEVER F. (eds.), Gendered Cities. Identities, activities, networks. A life-course approach, Rome, Società Geografica Italiana, pp. 227-243.

TIMÁR J. \& FÁBIÁN JELENSZKYNÉ I. (2004), “Female representation in the higher education of geography in Hungary“, Journal of Geography in Higher Education, 28 (1), pp. 101-110.

TIMÁR J. (2005), "Gender and spatial inequalities in Hungary in the transition era", in BARTA GY., G.FEKETE É., KUKORELLI SZÖRÉNYINÉ I. \& TIMÁR J. (eds.), Hungarian Spaces and Places : Patterns of Transition, Pécs, Centre for Regional Studies, pp. 307-322.

VÁRADI M. M. (2005), "Increasingly fossilized labour market structures and strategies of liveliehood : Chances of disadvantaged groups in the labour market", in BARTA GY. G.FEKETE É., KUKORELLI SZÖRÉNYINÉ I. \& TIMÁR J. (eds.), Hungarian Spaces and Places : Patterns of Transition, Pécs, Centre for Regional Studies, pp. 289-306.

VOICULESCU S. \& LELEA M. A. (2003), “A review of gender and geography and its development in Romania“, Analele Universitatii de Vest din Timisoara, GEOGRAFIE, XIII, pp. 123-144.

VOICULESCU S. (2004), "Rethinking women's bodies ; from uniforms to sexual freedom", in CORTESI G., CRISTALDI F. \& DROOGLEEVER F. (eds.), Gendered Cities. Identities, activities, networks. A life-course approach, Rome, Società Geografica Italiana, pp. 57-68.

\section{NOTES}

1. Since then their number has risen to 164 , and three more roundtables have been organised (http ://www.mona-hungary.org).

2. For a detailed discussion of the roundtable, see http ://www.mona-hungary.org and Pigniczky, 1997.

3. As researchers in the post-socialist region do not use the term consistently I use them as synonyms.

4. It should be noted that it was through my personal connections rather than by means of lending libraries that I had access to some of the above articles and books. Because of financial constraints, traditional lending libraries are a less and less viable means of access.

5. I managed to gather information mainly on the eight countries (excluding Germany) which, as socialist countries, were classified as East Central Europe before 1990, and the Ukraine (one geographer). Therefore, even if the "countries of origin" of the papers referred to in the next sub-section do not entirely cover the geographical area, I continue to use the term "East Central Europe".

6. The course that would have constituted part of the gender course discussed above could not be run. It was to have been part of a sequence of two that I was planning but which were not included in the curriculum for "organisational reasons" despite the fact that my previous courses in the early and mid-1990s were favourably received by students. 
7. It should be noted that like some critics in the West (see in Duncan, 1996 ; Perrons and Gonäs, 1998), Hungarian sociologist Zsuzsa Ferge (1999) also found that comparing reality with this theory was problematic.

8. For a summary of the findings of papers addressing similar issues, see, e.g. Łobodziñska, 1995b.

9. For a more detailed discussion of the issue, see the next sub-section.

10. For a summary of a rich technical literature on the latter issue, see Monk et al., 2004.

11. This pertains to the proportion of women studying geography in higher education in Hungary in the 1990s.

12. It should be noted that, according to a study, in post-socialist countries "lower sensitivity" is common, which can be observed with respect to the injustices and discrimination against women on grounds of sex (Neményi, 1994).

13. For the former approaches ("public"), see Ciechocinska, 1993, Timár, 2000, Gerasymenko, 2002 ; the latter ("private") is mainly used in combination with the former, see e.g. Timár, 2002, 2005.

14. The former ("public") approach is dominant in, for example, Meusburger, 2001, while the latter is a more dominant or the only approach in van Hoven-Iganski, 2000, Lelea, 2000, Ashwin, 2002, Hardy \& Stenning, 2002, van Hoven and Pfaffenbach, 2002, van Hoven, 2003.

15. For the summary of a few findings of co-disciplines (sociology, in particular), see Łobodziñska, 1995c.

16. For the summary of a few findings of co-disciplines on the region, see e.g. Corrin, 1992.

17. For those whom economic transition has not displaced "from the more 'public' realms of work to the more 'private' realms of the 'home'", as a result of which the latter means "isolation rather than comforting solitude" (Hörschelmann and van Hoven, 2003 : 754). This change in the meaning of "public-private" feminist has been revealed by geography from East Central Europe rather than feminist geography of East Central Europe.

18. According to McDowell, in this era margins became important places, where, paradoxically enough, feminists' marginality placed feminists centrally in the contemporary changes (e.g., a cultural shift) of geography.

\section{ABSTRACTS}

This paper draws on East Central European experience with the aim of understanding the nature of Anglo-American hegemony in feminist geography and of voicing subtle criticism of that hegemony. It identifies changes that are necessary to counter this situation and suggests means of bringing them about. Towards this end, it considers two issues. First it examines the forms of hegemony that are experienced by East-Central European feminist geographers and their implications for the development of gender studies/feminist geography in the region. Second it looks at the characteristics of feminist geography in the post-socialist region. With respect to the latter, it focuses on the social and institutional root causes of the time lag in/lack of its emergence. Although the paper mainly presents the differences in the production of knowledge in feminist geography, the author considers it equally important to face inequalities if shared strategies are to be formulated and political actions are to be taken.

L'objectif de cet article est de contribuer, à travers l'experience des pays d'Europe centrale et orientale, à la compréhension et la critique de l'hégémonie anglo-américaine sur la géographie 
féministe. Il identifie les changements nécessaires au renversement de cette hégémonie et suggère la manière de les appliquer. Pour atteindre ce but, l'article prend en considération deux questions. Premièrement, il examine les formes d'hégémonie qui sont vécues par les géographes féministes de l'Europe centrale et orientale ainsi que leurs implications dans le développement des études de genre/de la géographie féministe dans la région. Deuxièmement, il se penche sur les caractéristiques de la géographie féministe dans la région post-socialiste, et plus particulièrement sur les causes sociales et institutionnelles de son retard temporel et/ou de son absence. Bien que cet article présente principalement les différences dans la production de connaissance en géographie féministe, l'auteur considère qu'il est aussi important de faire face aux inégalités si des stratégies partagées doivent être formulées que de mettre en place des actions politiques.

INDEX

Mots-clés: géographie féministe, post-socialiste, Europe centrale et orientale, hégémonie Keywords: feminist geography, post-socialist, East-Central Europe, hegemony

\section{AUTHOR}

\section{JUDIT TIMÁR}

Alföld Institute, Centre for Regional Studies, Hungarian Academy of Sciences, Békéscsaba (Hungary), timarj@rkk.hu 